\title{
Mahdollisuuksia muutokseen
}

Soile Manninen

STKS:n Kirjastojuridiikan työryhmän 3.4.2017 järjestämä seminaari "Avoimuutta ja rajoituksia - miten uudistuva lainsäädäntö haastaa kirjastoja?" kokosi Tieteiden talolle tietosuojasta ja tekijänoikeudesta kiinnostuneet osallistujat erittäin ajankohtaisten asioiden äärelle.

Aalto-yliopiston tekijänoikeusasiamies Maria Rehbinder aloitti päivän puheenvuorot kertomalla tutkimusdataan sisältyvien henkilötietojen käsittelystä ja EU:n uudesta tietosuoja-asetuksesta. Rehbinder neuvoo omassa työssään Taideyliopistojen tekijänoikeuspalvelun kautta eri korkeakoulujen opiskelijoita ja osallistuu erilaisissa työryhmissä tekijänoikeuslainsäädännön kehittämiseen.

Rehbinder on tehnyt 23 vuotta tekijänoikeusjuridiikkaa ja sen rinnalle ovat nousseet viime vuosina tietosuoja-asiat. Hänen mielestään tekijänoikeuslainsäädännön jälkeen EU:n uusi yleinen tietosuoja-asetus (General Data Protection Regulation, GDPR) tuntuu järkevältä ja ymmärrettävältä, suorastaan kivalta.

\section{Yhteiset käytännesäännöt tarpeen}

Uuden yleisen tietosuoja-asetuksen päämäränä on tieteellisen tutkimuksen osalta yhtenäisen eurooppalaisen tutkimusalueen (European Research Area, ERA) vahvistaminen ja oikeudellisten esteiden poistaminen. Tieteellinen tutkimus on asetuksen mukaan tulkittava laajasti eli se voidaan ymmärtää perustutkimuksena, soveltavana tutkimuksena tai teknologian kehittämisenä.

Monilla mailla on helposti saatavilla oleva tutkimus- ja tiedepolitiikka, mutta Suomella ei sellaista ole. Rehbinderin mielestä tietosuojauudistuksen läpiviemisen tueksi tarvitaan selkeät ja yhteiset käytännesäännöt, joihin voitaisiin ottaa mallia esimerkiksi Horizon 2020 -hankkeen käytännesäännöistä.
Yliopistoille ja korkeakouluille uudistus on todella suuri haaste, mutta koska kaikille korkeakouluille on samanlaiset säännöt, asia voitaisiin hoitaa yhteisesti. Tätä puoltaa myös se, että asialla on todella kiire. Mallia voitaisiin ottaa eurooppalaisista ja yhdysvaltalaisista korkeakouluista, joissa vastaavia järjestelyjä on jo tehty.

\section{Tietosuojauudistuksen ydin}

Kaikilta tutkimusprojekteilta vaaditaan jatkossa selvitys henkilötietojen käyttämisestä. Jos tietosuoja-asetuksesta olisi luettava vain yksi kohta, Rehbinder suosittelee 5 artiklaa, joka koskee henkilötietojen käsittelyn periaatteita ja osoitusvelvollisuutta. Asetuksen noudattaminen ei riitä, vaan noudattaminen pystyttävä osoittamaan omien dokumentoitujen prosessien ja asiakirjojen avulla. Tämä on tietosuojauudistuksen ydin. Kaiken rekisteriselosteiden pitää olla kunnossa, jos joku niitä kysyy.

Rekisterinpitäjä määräytyy sen mukaan, kenellä on todellista määräysvalta. Yliopistokirjastoja ajatellen rekisterinpitäjä on todennäköisesti työnantaja eli yliopisto. Opiskelijat on myös ohjeistettava todella tarkkaan.

Rehbinder painotti esityksessään, ettei uudistuksesta selvitä papyruksella ja sulkakynällä. Digitalisaation on oltava mukana tässä muutosprosessissa. Esimerkkinä hän käytti tietojen anonymisointia. Kaikkeen ennen anonymisointia tapahtuvaan tietojenkäsittelyyn on oltava lupa eli henkilön suostumus häntä koskevien henkilötietojen käsittelyyn. Henkilön on tiedettävä mitä hänestä kerätyllä tiedolla tehdään. Kun data on anonymisoitu, se voidaan julkaista. Datan avoimuus on hallinnolle tärkeä asia, joten prosessit on saatava kuntoon ja tiedotuksesta on huolehdittava.

Asiaan vaikuttavat tieteenalojen eettiset nor- 


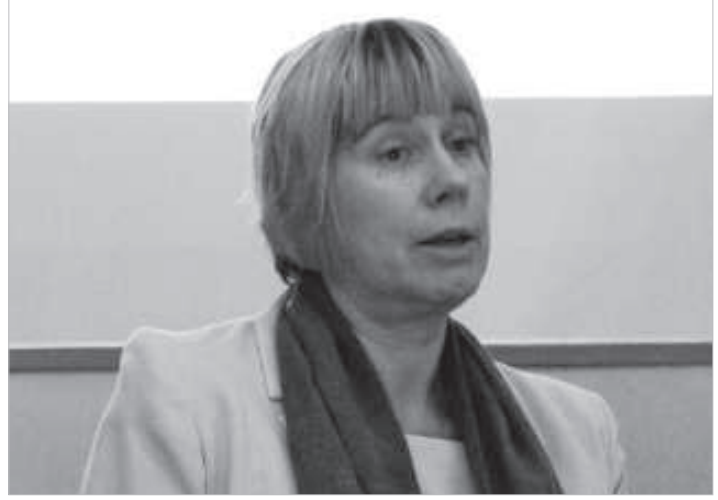

Kuva 1. Maria Rehbinder

mit ja jos niitä ei ole kirjattu mihinkään, eteenpäin meneminen on hankalaa. Tietuoja-asetus on pakottavaa EU-lainsäädäntöä, mutta säädösten osalta on kansallista liikkumavaraa, joka olisi hyödynnettävä. Näin pystyttäisiin turvaamaan kestävät ratkaisut pitkäaikaissäilytyksen ja aineistojen jatkokäytön sekä muiden tärkeiksi katsottujen asioiden kannalta.

\section{Tiesuoja ja kirjaston arki}

Kulttuurijohtaja Tuula Haavisto Helsingin kaupungilta avasi tietosuojauudistuksen mahdollisia käytännön vaikutuksia yleisille kirjastoille. Asiaa on mietitty Helmet-kirjastokimpan asiakkuustyöryhmässä, ja ryhmä on laatinut maaliskuussa 2017 hyväksytyn loppuraportin, jossa käsitellyt asiat koskevat kaikkia kirjastoja. Peruskäsitteiden kanssa on tultava tutuksi ja järjestelmien kanssa tulee kiire, mutta emme ole asian kanssa yksin. Tilanne on sama koko Euroopassa.

Ensiksi on tunnistettava mikä on henkilötieto, milloin se on julkinen ja mistä tiedoista syntyy henkilörekisteri. Uutta ajattelua on Haaviston mukaan se, että henkilötietoja ei enää kerätä tai säilytetä varmuuden vuoksi. Esimerkiksi henkilötunnuksia ei pitäisi enää kysyä joka paikkaan, vaan sen pyytämiseen on oltava perusteet. Kirjastokortti on luonteeltaan yksityisoikeudellinen sopimus, ja sen kautta tapahtuvan tiedon keräämisen on palveltava aineiston seurantaa.

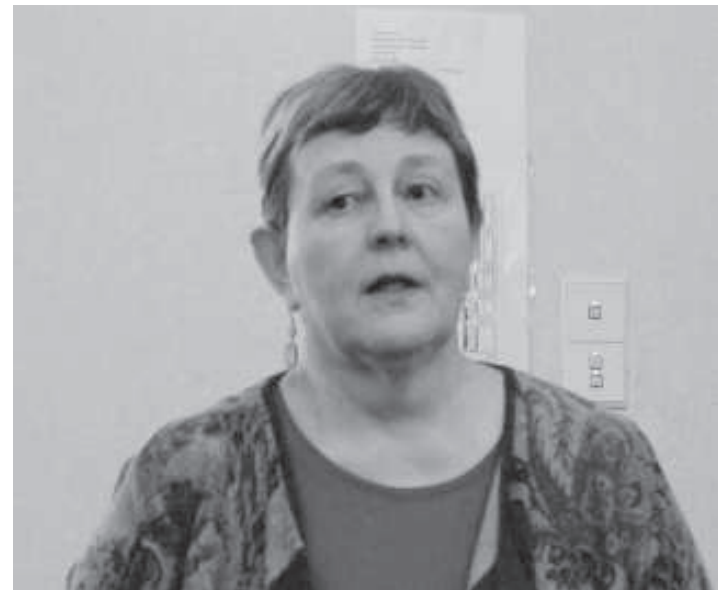

Kuva 2. Tuula Haavisto

Yhtä tarkoitusta varten kerättyä tietoa ei välttämättä saa käyttää muihin tarkoituksiin ja kaikki tietoihin liittyvä käyttö on dokumentoitava, jotta voidaan osoittaa, kuka on käsitellyt tietoja. Rekisteriselosteen pitää olla helposti saatavissa. Järjestelmissä on paljon yhteiskäyttötunnuksia, joista on todennäköisesti luovuttava.

Kirjastojärjestelmissä voi piillä muitakin riskejä. Haavisto vertasi järjestelmiä räsymattoihin, joissa on erilaisia korjattuja virityksiä, jotka voivat avata "tunnellin” jonnekin. Tässä tullaan kysymykseen, miten nähdään kolmannet osapuolet, kuten erilaiset järjestelmätoimittajat, joilla on mahdollisuus päästä käsiksi henkilötietoihin. Tätä varten tarvittaisiin riskiarvio tietojenkäsittelystä eli kannattaa miettiä millaisiin tietoihin käsiksi pääseminen on tarpeellista. Koulutusta on oltava kaikille henkilötietoja käsitteleville ja otettaisiin osaksi perehdytystä.

EU:n uuden tietosuoja-asetuksen on sanottu mullistavan kaiken. Mitä kaikkea se muuttaa, sitä Haavistokaan ei osannut vielä sanoa.

\section{Avoimuus edellä rinnakkaistallentamiseen}

Varatuomari Marja-Leena Mansala on laatinut opetus- ja kulttuuriministeriön pyynnöstä selvityksen tieteellisten julkaisujen rinnakkaistallentamisesta, niiden saatavuuden edistämisestä ja hyödynnettävyydestä. Selvityksessä kartoitettiin eri- 
laisia vaihtoehtoja rinnakkaistallentamisen edistämiseksi. Liikkeelle lähdettiin avoimuuden periaatteesta. Se on yhteisenä pyrkimyksenä hallitusohjelmassa, EU:n erilaisissa suosituksissa, tutkimusrahoitukseen liittyvissä sopimuksissa ja yliopistojen julkaisupolitiikassa. Suunnilleen kaikilla yliopistoilla on jonkinlainen julkaisuohjelma, joka nivoutuu kirjastoihin.

Selvityksen tausta-ajatuksena on rinnakkaistallentamisen pyrkimys säilyttää ja turvata tieteellisten julkaisujen saatavuus. Toinen lähtökohta on se, että tekijänoikeus on aina tekijällä/tekijöillä. Vaihtoehtoisina ratkaisuina on tarkasteltu sopimuskäytäntöjen kehittämistä, oikeuksien siirtämistä yliopistolle tai oikeuksien luovutuksen rajoittamista.

Kustannussopimus on tutkijan harteilla, mutta hänen intressinään ei ole julkaisujen säilyttäminen hamaan tulevaisuuteen. Julkaisujen saatavuuden turvaaminen on yliopistojen intressi, joten on mietittävä, miten tätä pyrkimystä voitaisiin edistää. Lainsäädännöllä ei voi luoda sopimuspakkoa, mutta mikään lainsäädäntöratkaisu ei sulje sopimista pois. Sopimuskulttuurin pitäisi tukea sitä, että kustannussopimuksessa tietty oikeus jäisi tutkijalle. Suurin ongelma tällä hetkellä on, että tutkijat eivät tiedä onko heillä oikeutta rinnakkaistallentamiseen.

\section{Muutos tekijänoikeuslakiin}

Selvityksessä esitetään ratkaisusuosituksena uuden momentin lisäämistä tekijänoikeuslain 27\$:ään, jossa annetaan yleiset määräykset tekijänoikeuden luovutuksesta. Muutoksella rajoitettaisiin tekijänoikeuteen liittyvien taloudellisten oikeuksien luovutusta niin, että tekijälle jäisi oikeus rinnakkaistallentamiseen $\mathrm{mm}$. ei-kaupalliseen ja tie-

\section{Keskeisiä käsitteitä uudessa yleisessä tietosuoja-asetuksessa}

Henkilötieto: kaikki tunnistettuun tai tunnistettavissa olevaan luonnolliseen henkilöön (rekisteröityyn) liittyvät tiedot.

Rekisteri: mikä tahansa jäsennelty henkilötietoja sisältävää tietojoukko. Rekisterinpitäjä: luonnollinen henkilö tai oikeushenkilö, viranomainen, virasto tai muu elin, joka yksin tai yhdessä toisten kanssa määrittelee henkilötietojen käsittelyn tarkoitukset ja keinot.

Osoitusvelvollisuus: Henkilötietojen käsittelyä koskevat periaatteet, joita rekisterinpitäjän on noudatettava: lainmukaisuus, kohtuullisuus ja läpinäkyvyys; käyttötarkoitussidonnaisuus; tietojen minimointi; täsmällisyys; säilytyksen rajoittaminen; eheys ja luottamuksellisuus. Rekisterinpitäjän tulee pystyä osoittamaan, että näitä kohtia on noudatettu esim. käytännesääntöjen tai sertifioinnin avulla.

Henkilötietojen käsittelijä: luonnollinen henkilö tai oikeushenkilö, viranomainen, virasto tai muu elin, joka käsittelee henkilötietoja rekisterinpitäjän lukuun.

Rekisteröidyn suostumus: Mikä tahansa vapaaehtoinen, yksilöity, tietoinen ja yksiselitteinen tahdonilmaisu, jolla rekisteröity hyväksyy henkilötietojensa käsittelyn antamalla suostumusta ilmaisevan lausuman tai toteuttamalla selkeästi suostumusta ilmaisevan toimen. Rekisteröidyllä on oikeus peruuttaa suostumuksensa milloin tahansa.

Oikeus poistaa tiedot ("oikeus tulla unohdetuksi"): rekisterinpitäjän on poistettava henkilötiedot, jos niitä ei enää tarvita märiteltyyn käyttötarkoitukseensa, rekisteröity peruuttaa suostumuksensa eikä muuta oikeuttamisperustetta ole.

Käytännesäännöt: niiden avulla tuetaan asetuksen asianmukaista soveltamista erityisesti ottaen rekisterinpitäjien erityistarpeet ja sektorien erityispiirteet huomioon. 
luopua kaikista oikeuksista, vaikka se olisi laissa. Mansala myönsi ajatusmallin olevan hieman absurdi: tekijänoikeutta rajoitettaisiin, mutta ainoastaan tekijä voisi tätä rajoitusta käyttää.

\section{Mallia korkeakoulukeksintölaista?}

Isossa-Britanniassa on kehitetty Harvardin yliopiston esimerkin pohjalta lisensointimallia, jossa yliopistoille mahdollistettaisiin tutkijoidensa artikkeleiden rinnakkaisjulkaiseminen CC-lisenssillä ei-kaupallisiin tarkoituksiin. Ranskassa tutkijalle jää oikeus rinnakkaistallentamiseen ja laki tutkimuksesta on erillinen. Yhdysvalloissa valtion rahoittamissa yliopistoissa oikeudet jäävät yliopistolle eli valtiolle.

Jos Suomessa päädyttäisiin ratkaisuun, jossa tutkijan olisi siirrettävä oikeuksia yliopistolle, Mansala ehdottaa ottamaan mallia vuonna 2007 voimaantulleesta korkeakoulukeksintölaista, jota uudistetaan parhaillaan. Lailla pyritään edistämään korkeakouluissa syntyneiden keksintöjen tunnistamista, suojaamista ja hyödyntämistä keksijän, yhteiskunnan ja korkeakoulujen kannalta tarkoituksenmukaisella tavalla.

Kyseisen lain uudistaminen on jo pitkällä työja elinkeinoministeriössä, joten tässä vaiheessa voi vain hahmotella millainen nimi ja sisältö tällaisella säädöksellä olisi. Tätä polkua ei kuitenkaan kannata hylätä. Siirtosäännöksen ottamista lakiin tulisi tulevaisuudessa harkita, mutta tällä hetkellä tekijänoikeuslain muuttaminen näyttäisi olevan helpoin tapa.

\section{Yhteisen edun nimissä}

Seminaariyleisöä mietitytti kustantajien reagointi mahdolliseen tekijänoikeuslain muutoksen ja miten tämä näkyisi kustannussopimuksissa. Muutos voisi auttaa neuvotteluissa kustantajien kanssa ja antaisi FinELib:lle paremmat neuvotteluasemat, mutta vaikuttaisiko se oikeasti suuriin kansainvälisiin kustantajiin ja miten se näkyisi tutkijoiden käyttämissä julkaisukanavissa? Lainsädännöllä ei pystytä puuttumaan eri tieteenalojen julkaisukäytäntöihin, mutta muutos loisi mahdollisuuden vaikuttaa.

Kysymyksiä herättivät myös vaihtelevat embargo-käytännöt. Jotkut rahoittajat vaativat välitöntä julkaisemista ja toisaalta tutkija on voinut kirjoittaa sopimuksen 48 kuukauden embargoajasta. Tutkijoita neuvotaan säilyttämään rinnakkaistallentamisoikeus, mutta jos kustantaja vaatii kaikki oikeudet, ne on annettava. Vaikka muutos saataisiin tekijänoikeuslakiin, avoimuudesta huolehtiminen olisi edelleen yliopistojen ja tutkimuslaitosten vastuulla. Pitää jalkautua tutkijoiden keskuuteen ja iskostaa ajatusta siitä, että rinnakkaisjulkaiseminen on yhteinen etu. Tämä voi viedä aikaa.

\section{Koulutukselle on tarvetta}

Iltapäivä vierähti työryhmätyöskentelyssä, jonka aikana keskusteltiin päivän puheenvuorojen lisäksi uuden tietosuoja-asetuksen vaikutuksista kirjastojen arkeen. Helsingin yliopisto on jo edennyt tässä asiassa, muissa korkeakouluissa tilanne on vaihteleva. Henkilöstön osaaminen ja asiantuntemus on pystyttävä osoittamaan, ja keskusteluissa nostettiin erääksi vaihtoehdoksi tietosuojaan liittyvä verkkotesti henkilötietoja käsitteleville työntekijöille.

Kaikissa työryhmissä nostettiin esille kouluttautumisen tärkeys. Yleisen tietosuoja-asetuksen soveltaminen alkaa 25.5.2018 ja kirjastojen henkilöstö olisi koulutettava ennen sitä. Asia kuuluu kaikille, ei pelkästään kirjastojen henkilökunnalle. Seminaari oli vasta herättelyä ja asian eteenpäin viemiseksi tarvitaan laajempaa kansallista yhteistyötä. 


\section{Lähteet:}

Euroopan parlamentin ja neuvoston asetus (EU) 2016/679 (General Data Protection Regulation "GDPR")

http://www.tietosuoja.fi/ > EU:n tietosuojauudistus $>$ Sanastoa

EU:n tietosuojavaltuutetuista koostuva WP29-tietosuojatyöryhmä päivittää tarkempia ohjeita.

Marja-Leena Mansalan selvitys julkaistaan OKM:n verkkosivuilla.

\section{Tietoa kirjoittajasta:}

Soile Manninen

tietoasiantuntija

IPR University Center

manninen@iprinfo.com

Kirjoittaja edustaa STKS:n Kirjastojuridiikan

työryhmässä erikoiskirjastoja. 